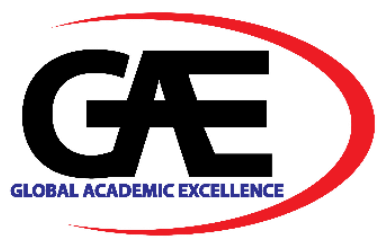

\title{
BARRIERS TO THE DEVELOPMENT OF OCCUPATIONAL HEALTH AND SAFETY MANAGEMENT SYSTEMS IN THE NIGERIAN CONSTRUCTION INDUSTRY
}

\author{
Adetunji Kamoli ${ }^{*}$, Razali Adul Hamid ${ }^{2}$, Syamsul Hendra Mahmud ${ }^{3}$
}

1 Department of Quantity Surveying, Faculty of Built Environment and Surveying, Universiti Teknologi Malaysia. Email: qsakinadetunji@gmail.com

2 Department of Quantity Surveying, Faculty of Built Environment and Surveying, Universiti Teknologi Malaysia. Email: b-razali@utm.my

3 Department of Quantity Surveying, Faculty of Built Environment and Surveying, Universiti Teknologi Malaysia.

Email: b-syamsul@utm.my

* Corresponding Author

\section{Article Info:}

Article history:

Received date: 01.10 .2021

Revised date: 01.11 .2021

Accepted date: 20.11.2021

Published date: 01.12.2021

To cite this document:

Kamoli, A., Hamid, R. A., \& Mahmud, S. H. (2021). Barriers To The Development Of Occupational Health And Safety Management Systems In The Nigerian Construction Industry. Journal of Information System and Technology Management, 6 (24), 90-99.

\section{DOI: $10.35631 / J I S T M .624009$}

This work is licensed under CC BY 4.0

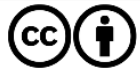

Abstract:

OHSMS has become the main part of the establishment's lifeline and a prerequisite for its stability in the 21 st century. There is a growing need for OHSMS, in its ability to solve occupational accidents and also to develop a robust relationship among the stakeholders. The mission of OHSMS has not been followed in the Nigerian construction industry. The study, therefore, explores the barriers to the development of OHSMS in the Nigerian construction industry. The study adopted a literature review of OHSMS and thereafter, 300 structured questionnaires were administered to the construction professionals in the built environment of the Nigerian nation's Capital-Abuja. 247 of the administered questionnaires were returned, considered for the analysis of the study. The data were analysed with SPSS and excel. The findings of the study indicate that the lack of commitment of the government, inefficient regulatory authorities, and lack of expertise in the OHS activities are the major barriers to the development of OHSMS. The study recommends collaborative efforts from the construction organizations, employees, and construction professionals to support the government on the OHSMS.

Keywords:

Health, Construction Industry, Occupational Accident, Management Systems, Safety 


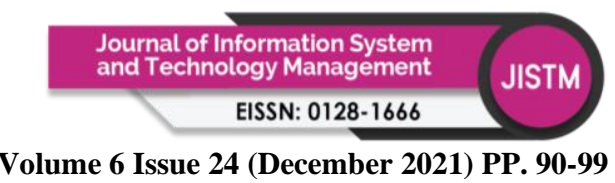

Volume 6 Issue 24 (December 2021) PP. 90-99 DOI: 10.35631/JISTM.624009

\section{Introduction}

Occupational accidents have continuously been a concern in the construction sector (ILO, 2014; Pellicer, et al., 2014; Zarei, et al., 2021). These occupational accidents not only influence the health and safety of employees but also their entire family structure (Construction Industry Institute, 2003; Top, et al., 2016). Also, occupational accidents are an origin of losses for construction organizations (Waehrer, et al., 2007). The social and economic impacts of occupational accidents are substantial. So, any contribution to support decreasing occupational accidents and illness in the construction sector can be considered worthy (Alarcón, et al., 2016). The recent social, economic, and technological changes impose responsibility on the establishments in various sectors, making them in search of a new managerial approach to support them in the improvement of practices and elimination of hazards. Also, (ILO, 2016) advocate for the establishment and application of OHSMS in the construction industry. As a result of this, many organizations in developed nations have established and applied OHSMS that improve the quality of their operations, sustainable development, enhancement of the coworkers' working environments, and prevention of occupational accidents (Oliveira, et al, 2010). Therefore, transforming the market burdens into competitive advantages.

Similarly, OHSMS has been an object of the focus of managers for identifying and minimizing the occupational hazards, offering continuous improvement, reliability, and rationalization of projects, practices, and products, reducing project expenditures, motivation, and improving the quality of life of employees and improvement of the establishment's image (ISO, 2018). The viewpoint of these outcomes becomes more important when considering the construction sector, due to its impact on the development and economy it provides for nations and at the global level. The construction employs approximately 5-10\% of the workforce in developed nations and the proportion may be more in developing countries (ILO, 2015b). But surprisingly, it accounts for $30 \%$ of the occupational fatal accidents, in industrialized nations, construction personnel are 3 to 4 times more likely to die due to accidents at construction sites, the number in developing nations will be probably 3 to 6 times higher (ILO, 2015a). Hence, accidents on construction sites are devastating throughout the world.

Furthermore, managing health and safety matters only by information, and the implementation of a legislative approach has been demonstrated to be less reliable in many cases (Carbonari, et al., 2011). Certainly, any alterations to project plans during the construction stage often involve new potential hazards. For this reason, there is always a hazard that employees may be unconscious of. In many cases, the application of the regulations often results in an inadequate implementation of mitigation measures. First, they evaluate what occurs after the incident and are reactive concerning management response. Second, in the nonexistence of any proactive measure, causative relationships cannot be recognized. Third, they are negative and recognized as being ineffective as a measure of safety performance (Marosszeky et al, 2004; Mohamed, 2003). Occupational health and safety management systems have to a great extent been established in response to these requirements.

To understand the conceptualization of a management system, first, it is essential to understand a system. According to (Jonker and Karapetrovic, 2004), systems refer to interwoven procedures that operate amicably, share similar human, information, material, infrastructure, and economic resources, all focused on the accomplishment of set policies, targets, and objectives. Whereas, a management system refers to a set of interrelated components that can be utilized to develop, apply, and accomplish various objectives and policies, based on the 


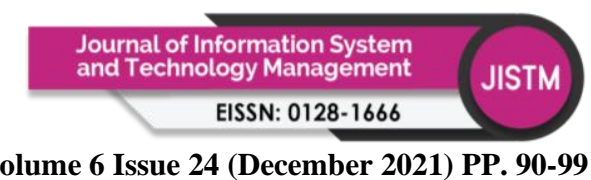

Volume 6 Issue 24 (December 2021) PP. 90-99 DOI: 10.35631/JISTM.624009 planning activities, practices, responsibilities, procedures, and resources (BSI, 2007). Similarly, OHSMS refers to a systematic method put in place at the organizations to reduce the risk of illness and injury (Bottomley,1999; Canada, 2018; Gallagher, 1997; Waring, 1996). So, management systems are made up of requirements associated with each other to meet a given objective. The goal of OHSMS is to control risks associated with OHS and to continuously improving health and safety working conditions in the organizations (Vitoreli and Carpinetti, 2013). OHSMS are different from traditional OHS programs as a result of being more proactive, better internally combined, and incorporating components of assessment and continuous improvement (Robson, et al., 2007).

Previous studies proved the effectiveness of the OHSMS. That is why OHSMS should be applied in the prevention of occupational accidents in the Nigerian construction industry. According to (Yoon, et al., 2013), the occupational accident rate reduced in Korea after the introduction of the OHSMS. Similarly, (Palassis, et al, 2006) highlighted the benefits of OHSMS which include job satisfaction and improved worker productivity, better organizational image, fulfillment of legal requirements, reduction of turnover of workforces, reduced lost workdays, improved worker health, and safety status, enhanced product quality, and reduced interruption of organization progress of work.

Also, OHSMS is regarded as a method of creating health and safety awareness, better understanding of occupational hazards, and commitment among all the workers and organizations (Fernández-Muñiz, et al, 2009). Well-implemented OHSMS could enable the development of a healthy and safer workplace and the creation of better operational results for the organizations (Allur, et al., 2018; Wiengarten, et al., 2017). Resilient OHSMS had the potential in eradicating the hazards on construction sites, particularly enhancing the risk perception of construction workers (Wang, et al, 2016). While (İnan, et al, 2017) draw the attention of OHSMS to very crucial contribution for control occupational risk, and bring out the significance of new social features of management on OHS.

The systems have been in operation in nations like the US, Singapore, Malaysia, Hong Kong, Australia and proved effective in the prevention of occupational injuries. The fatality rate of accidents has reduced in the nations with the following evidence. Malaysia [2003-12.7, 20193.1]. Singapore [2003-3.3, 2019-1.4], Hong Kong [2003 -8.6, 2019 -3.2], Australia [2003 2.0, 2019-16] and USA [2003 5.0, 2019-3.5] (Ministry of Manpower. Singapore, 2020)

No formal national OHSMS has been developed by OSH authorities for use in the workplace (Federal Ministry of Labour and Employment, 2016). But all organizations rely on the Factories act of 1990. The bad performance of OSH in the Nigerian construction industry has been associated with the absence of OHSMS, the hazards have not been following systematically, making the sector account for the highest number of work-related illnesses and injuries (Federal Ministry of Labour and Employment, 2016). The study, therefore, was conducted to explore barriers to the development of OHSMS in the Nigerian construction industry.

\section{Factors Contributing to the Rising of OHSMS}

Despite detailed rules, enforcement, and more instructions, the improvement in occupational risks remains a problem (Frick, et al., 2000). Organizations and their managers did not control the quality of OHS, hence, waiting to be informed what to do regarding each hazard (Kaj,1990). 


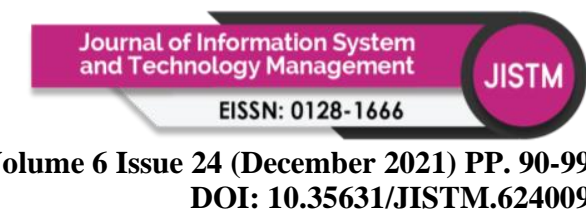

The deficiency in control was drawn from major global hazards where thousands of employees died and billions of dollars worth of properties were destroyed which include Oppa, Germany 1921, Honkeiko Colliery, China 1942, Texas City, USA 1947, Cali, Colombia 1956, Flixborough, UK 1974, Chasnala, India 1975, Seveso, Italy 1976, Novosibirsk, USSR 1979, Alexander Kielland 1980, Mexico City, Mexico 1984, Bhopal in India 1984, Chernobyl, USSR 1986, North Sea 1988 and Rana Plaza Bangladesh 2013 that were attributed to the bad application of OHS (Bowonder, 1987; Goetsch, 2011; ILO, 2013; Kasperson, et al., 1988; Robert, 2016; Woolfson, et al., 1997). Similarly, different kinds of injuries such as musculoskeletal were beginning to be arousing (MacLeod, 1994). These factors have been contributed to the growing OHSMS approach and including the broad OHS reformations of the 1970s and 1980s (Frick et al., 2000; Clare et al, 2001; Gustavsen, 1985). Most industrialized nations reviewed their health and safety regulations in the 1970s. The initiatives had three key principles of government intervention (Stolk, et al., 2012). First, there was a focus on the obligation of organizations for OSH policy. Second, the initiatives established better standards and complete legislation, that were still fragmented in several nations, to increase health and safety at work, and to better impose regulation. Third, they encouraged employees' participation in $\mathrm{OSH}$ policy.

Furthermore, other factors for the rising of OHSMS were complications in working lifetime, the rising dominance of multi-factorial illnesses like cancer, physical fatigue, and heart ailments, the increased focus on new issues like stress, and the developing ecological frame of reference for the consideration of the relationship between environment and man (Commonwealth of Australia, 2012). Also, in many nations, employee preoccupation with safety and health was forcefully articulated through strikes. Most recognized in Scandinavia was the LKAB clash in a public-sector mining organization in Northern Sweden (Dählström et al, 1971). The emergence of the British Robens Report (1972), with its adoption of establishment self-regulation, was also the main catalyst of change (Browne, 1973). The Scandinavian work environment reorganizations were similarly instrumental both within the statute law institution in most of Europe and other nations like Canada and Australia (Sass, 1989). A study by the OHSAS Project Group established that there were an increase in OHSMS certification in some countries from 70 to 102 between 2003 to 2007 and the figure of OHSAS 18001 certification increase from 3,898 to 31,512 (IOSH, 2015). The increase in the international scope of occupation and supply chain demand, reinforced through the growing acceptance of OHSMS by regulatory bodies if implement correctly will support a better quality of health and safety, legal conformity and also increase OSH performance in the organizations.

\section{Method}

This study examines the barriers to the development of OHSMS in the Nigerian construction industry. Comprehensive information on OHSMS was acquired through literature. This forms the basis of information for the questionnaire compilation. Thereafter, 300 structured questionnaires were distributed to solicit information used for the study. The first segment of the questionnaire was about their general information, while the other part focused on the roles of the barriers to the development of OHSMS in the Nigerian construction industry. The respondents' selections of answers are arranged in a five-point Likert scale from strongly disagree to strongly agree. The respondents of the study were construction professionals in the Federal Capital Territory, Abuja, Nigeria. 247 of the questionnaires that were returned represent $82.33 \%$. 


\section{Data Analysis}

The collected data were analyzed by SPSS software and Microsoft Excel. The data reliability was conducted with Cronbach alpha. This is to test the internal consistency of the instrument. Value of Cronbach's alpha range from 0 to 1. Ursachi et al, (2015) highlighted that Cronbach alpha greater than 0.7 " is acceptable, but values greater than 0.8 " are more satisfactory. The Cronbach alpha of the instrument was 0.87 . The result is within the acceptable value. The data were afterward analysed through descriptive statistics. The relative importance index was employed and ranked. The Relative Importance Index (RII) calculation

$$
R I I=\frac{\sum w}{A x N}
$$

$\mathrm{W}=$ represent weighting given on each of the factors by the respondents range from 1-5. 1 represent strongly disagree, 2 represents disagree, 3 represents undecided, 4 represents agree, 5 represents strongly agree. The total number of respondents is $\mathrm{N}=247$, A represents the highest weight $=5$.

\section{Result}

Table 1 shows the result of barriers to the development of OHSMS in Nigerian construction. The result of the study indicates that lack of commitment of the government and inefficient regulatory authorities are the major barriers to the development of OHSMS in the Nigerian construction industry.

Table 1: Barriers to The Development of OHSMS

\begin{tabular}{lccccc}
\hline \multicolumn{1}{c}{ Variables } & Sum & Mean & Std.dv & RII & Rank \\
\hline $\begin{array}{l}\text { Lack of commitment of the Government } \\
\text { Inefficient regulatory authorities }\end{array}$ & 1102 & 4.46 & 0.500 & 0.892 & 1 \\
$\begin{array}{l}\text { Lack of expertise in OHS activities } \\
\text { Lack of commitment of leadership within }\end{array}$ & 1102 & 4.46 & 0.500 & 0.892 & 1 \\
$\begin{array}{l}\text { organizations } \\
\text { Lack of management strategies }\end{array}$ & 1064 & 4.31 & 0.723 & 0.862 & 3 \\
Prioritization of production over health and safety & 1064 & 4.31 & 0.607 & 0.862 & 3 \\
Lack of health and safety awareness & 1045 & 4.23 & 1.189 & 0.846 & 5 \\
Short term thinking & 1045 & 4.23 & 0.892 & 0.846 & 5 \\
Absent or ineffective communication among & 1026 & 4.15 & 1.028 & 0.831 & 7 \\
stakeholders & 1026 & 4.15 & 0.771 & 0.831 & 7 \\
Economic pressure & & & & & \\
Failure to start small & 1026 & 4.15 & 0.771 & 0.831 & 7 \\
Inadequate allocation of resources to H\&S & 1007 & 4.08 & 1.209 & 0.815 & 10 \\
Inadequate OHS policy & 1007 & 4.08 & 0.919 & 0.815 & 10 \\
Lack of knowledge of the effect of the interventions & 988 & 4.00 & 1.112 & 0.800 & 12 \\
Bureaucracy & 969 & 3.92 & 1.209 & 0.785 & 12 \\
Difficulties in the interaction with external agencies & 969 & 3.92 & 0.919 & 0.785 & 13 \\
Difficulty in planning the OHS activities & 969 & 3.92 & 0.731 & 0.785 & 13 \\
Lack of support of Trade union & 930 & 3.85 & 1.101 & 0.769 & 16 \\
& 931 & 3.77 & 1.189 & 0.754 & 17 \\
& 931 & 3.77 & 1.122 & 0.754 & 17
\end{tabular}


Lack of technical support from construction professionals

\section{Discussion}

The study examines the barriers to the development of OSHMS in the Nigerian construction industry. OHSMS is the process of organizing and harmonize financial, human, and other resources in a standardized manner, and certify that mechanisms are positioned to monitor and manage OHS arrangements. OHSMS requires government intervention for the development and application. It was highlighted by (ILO, 2004, 2015b) that a high level of political commitment is required in the establishment and application of OHSMS. Regulatory authorities also offer models and guidance on OHSMS (Bluff, 2003), while collaborative efforts of the organizations, employees, and construction professionals are important in its application for the system to be effective and succeed. OHSMS needs a control structure in the organization this will enable a clear-cut distribution of responsibilities to different levels of management and units of the workplace and also allows management to completely manage its work processes. OSH experts need to understand an organization's vision, plan, and value chain to institute an integrated OSH structure. The human element is important for creating a workplace that has an intrinsic emphasis on OSH. Health and safety leadership from top management is crucial for an organization, as it ultimately supports the application of resources and moderates engagement with other organizational main concerns. Proactive and positive styles of leadership like constructive or transformational leadership can influence safety and health behaviour within organizations. Similarly, management commitment to OSH can impact behaviours positively, especially when a participating method is in place. Leadership, on the whole, can support the health and safety process particularly when noticeable aspects of a commitment to OSH are exhibited.

\section{Conclusion}

The need for OHSMS in the Nigerian construction industry context is important for the prevention of occupational accidents consider the culture and work practices and the system is required to develop a strategy applying (1) organizational structure of HS with responsibilities, roles, and authorities, (2) systematic processes to health and safety and associated resources, (3) measurement and evaluation of HS methodology to assess its performance and (4) review process to guarantee problems are identified, corrected and corrections are implemented. OHSMS for the construction industry has been applied in some nations based on the practices for that nation. The numbers of factors used in the development of the system vary from one nation to another subject on the distinct needs of the local construction industry.

OHSMS provides employers and employees with a better understanding of health and safety risks. When applied correctly, an OSHMS address health and safety matters, strike the right balance in managing all hazards. An appropriate application of OSHMS will ensure suitable $\mathrm{OSH}$ objectives are set by focusing on policy on the intervention measure for accident prevention. To further improve and promote employees' health and safety, organizations need to go beyond the common regulations, focus on how perfect to recognize potential hazards in their particular area of work, and follow their health and safety record. Establishments with experience in managing important internal processes should find it relatively simple to develop OSHMS by using similar methods while establishments without such experience may require 
to engage external management consultants to support effective deliberation and to ensure the participation and commitment of all important parties. OHSMS must be comprehensively designed and apply, this is to allow organizations and workers to not only identify hazards but also communicate with each other through the construction stages.

\section{References}

Alarcón, L. F., Acuna, D., Diethelm, S., \& Pellicer, E. (2016). Strategies for improving safety performance in construction firms. Accident Analysis and Prevention, 94, 107-118. https://doi.org/10.1016/j.aap.2016.05.021

Allur, E., Heras-Saizarbitoria, I., Boiral, O., \& Testa, F. (2018). Quality and Environmental Management linkage: A review of the literature. Sustainability (Switzerland), 10(11), 1-15. https://doi.org/10.3390/su10114311

Bluff, L. (2003). Systematic Management of Occupational Health and Safety (No. 20).

Bottomley, B. (1999). Occupational health \& safety management systems : strategic issues report.

Bowonder, B. (1987). The Bhopal accident. Technological Forecasting and Social Change, 32(2), 169-182. https://doi.org/10.1016/0040-1625(87)90038-2

Browne, R. C. (1973). Notes and miscellanea Safety and health at work : The Robens Report. Brit. J. Industr. Med., 30, 87-91.

BSI. (2007). OHSAS 18001:2007 - Occupational Health and Safety Assessment Series . Occupational health and safety management systems. In OHSAS Project Group 2007. https://doi.org/978 0580508028

Canada, E. S. (2018). Introduction to health and safety management systems.

Carbonari, A., Giretti, A., \& Naticchia, B. (2011). A proactive system for real-time safety management in construction sites. Automation in Construction, 20(6), 686-698. https://doi.org/10.1016/j.autcon.2011.04.019

Commonwealth of Australia. (2012). A Systematic Review of the Effectiveness of Safety Management Systems-. Australian Transport Safety Bureau.

Construction Industry Institute. (2003). Safety Plus: Making Zero Accidents A Reality Prepared. Austin, Texas: Construction Industry Institute, The University of Texas at Austin.

Dählström et al. (1971). LKAB och demokratin. Stockholm. Stockholm: Wahlström \& Widstrand.

Federal Ministry of Labour and Employment. (2016). Nigeria Country Profile on Occupational Safety and Health. In Federal ministry of labour and employment.

Fernández-Muñiz, B., Montes-Peón, J. M., \& Vázquez-Ordás, C. J. (2009). Relation between occupational safety management and firm performance. Safety Science, 47(7), 980991. https://doi.org/10.1016/j.ssci.2008.10.022

Frick, K., Jensen, P. L., Quinlan, M., \& Wilthagen, T. (2000). Systematic Occupational Health and Safety Management Perspectives on An International Development. (First edit). UK: Elsevier Science Ltd.

Gallagher., C. (1997). Health and safety management system: An analysis of safety system types and effectiveness.

Gallagher, Clare, Underhill, E., \& Rimmer, M. (2001). Occupational Health and Safety Management: A Review of their Effectiveness in Securing Healthy and Safe Workplaces. In National Occupational Health and Safety Commission. https://doi.org/10.1002/9781118131350.ch25 
Goetsch, D. L. (2011). Occupational Health and Safety: For Technologists, Engineers, and Managers (7th ed.). Pearson. https://doi.org/10.1201/9781315269603-5

Gustavsen, B. (1985). Workplace Reform and Democratic Dialogue. Economic and Industrial Democracy, Vol. 6, pp. 461-479. https://doi.org/10.1177/0143831X8564004

ILO. (2004). Global strategy on occupational safety and health: Conclusions adopted by the International Labour Conference at its 91st Session, 2003. International Labour Organization, 1-20.

ILO. (2013). Bangladesh Move towards Employment injury Insurance: The Legacy of Rana Plaza. ILO Global Employment Injury Insurance Programme, 1-3. Retrieved from http://www.ilo.org/geip

ILO. (2014). Safety and Health at Work: A Vision for Sustainable Prevention.

ILO. (2015a). Construction: a hazardous work.

ILO. (2015b). Good practices and challenges in promoting decent work in construction and infrastructure projects. Retrieved from http://www.ilo.org/wcmsp5/groups/public/--ed_dialogue/---sector/documents/publication/wcms_416378.pdf

ILO. (2016). Occupational safety and health management in the construction sector. International Labor Organization, 1-2.

İnan, U. H., Gül, S., \& Yılmaz, H. (2017). A multiple attribute decision model to compare the firms' occupational health and safety management perspectives. Safety Science, 91, 221-231. https://doi.org/10.1016/j.ssci.2016.08.018

IOSH. (2015). Systems in focus: Guidance on occupational safety and health management systems. Retrieved from www.iosh.co.uk/ freeguides

ISO. (2018). ISO 45001:2018 Occupational health and safety management systems Requirements with guidance for use.

Jonker, J., \& Karapetrovic, S. (2004). Systems thinking for the integration of management systems. Business Process Management Journal, 10(6), 608-615. https://doi.org/10.1108/14637150410567839

Kaj Frick. (1990). Can Management Control Health and Safety at Work? Economic and Industrial Democracy, Vol. 11, pp. 375-399. https://doi.org/10.1177/0143831X90113005

Kasperson, R. E., Kasperson, J. X., Hohenemser, C., Kates, R. W., \& Svenson, O. (1988). Corporate Management of Health and Safety Hazards. In Corporate Management of Health and Safety Hazards. https://doi.org/10.4324/9780429042706

MacLeod, D. (1994). The ergonomics edge- improving safety, quality, and productivity. Wiley. Marosszeky et al. (2004). Lessons Learnt in Developing Effective Performance Measures for Construction Safety Management. 12th Annual Conference of the International Group for Lean Construction. from http://iglc.net/Papers/Details/314/pdf\%0Ahttp://iglc.net/Papers/Details/314

Ministry of Manpower. Singapore. (2020). Workplace Safety and Health Report 2019-National Statistics. $\quad$ Retrieved from https://www.wshinstitute.sg/files/wshi/upload/cms/file/WSHI National Statistics Report 2014.pdf

Mohamed, S. (2003). Scorecard approach to benchmarking organizational safety culture in construction. Journal of Construction Engineering and Management, 129(1), 80-88. https://doi.org/10.1061/(ASCE)0733-9364(2003)129:1(80)

Oliveira, O. J. de, Oliveira, A. B. de, \& Almeida, R. A. de. (2010). Management \& Production Guidelines for the implementation of occupational health and safety systems in companies producing automotive batteries. Gestão \& Produção, 17(2), 407-419. 


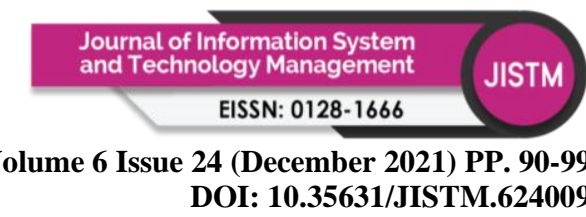

Palassis, J., Schulte, P. A., \& Geraci, C. (2006). A new American management systems standard in occupational safety and health - ANSI Z10. Journal of Chemical Health and Safety, 13(1), 20-23. https://doi.org/10.1016/j.chs.2005.09.002

Pellicer, E., Carvajal, G. I., Rubio, M. C., \& Catalá, J. (2014). A method to estimate occupational health and safety costs in construction projects. KSCE Journal of Civil Engineering, 18(7), 1955-1965. https://doi.org/10.1007/s12205-014-0591-2

Robert H. Friis. (2016). Occupational Health and Safety for the 21 st Century. United States of America: Jones \& Bartlett Learning.

Robson, L. S., Judith A. Clarke, Cullen, K., Bielecky, A., Severin, C., Bigelow, P. L., ... Mahood, Q. (2007). The effectiveness of occupational health and safety management system interventions: A systematic review. Safety Science, 45(3), 329-353. https://doi.org/10.1016/j.ssci.2006.07.003

Sass, R. (1989). The implications of work organization for occupational health policy : the case of Canada. International Journal of Health Services, 19(1), 157-173.

Stolk, C. van, Staetsky, L., Hassan, E., \& Kim, C. W. (2012). Management of occupational safety and health: An Analysis of the findings of the European Survey of Enterprises on New and Emerging Risks (ESENER)-European Risk Observatory. Luxembourg. https://doi.org/10.2802/90924

Top, Y., Adanur, H., \& Vocational, M. Ö. (2016). Comparison of practices related to occupational health and safety in microscale wood-product enterprises. Safety Science, 82, 374-381. https://doi.org/10.1016/j.ssci.2015.10.014

Ursachi, G., Horodnic, I. A., \& Zait, A. (2015). How Reliable are Measurement Scales? External Factors with Indirect Influence on Reliability Estimators. Procedia Economics and Finance, 20(15), 679-686. https://doi.org/10.1016/s2212-5671(15)00123-9

Vitoreli, G. A., \& Carpinetti, L. C. R. (2013). Analysis of the integration of normalized management systems ISO 9001 and OHSAS 18001: Multiple case studies. Gestão \& Produção, 20(1), 204-217. https://doi.org/10.1590/S0104-530X2013000100015

Waehrer, G. M., Dong, X. S., Miller, T., Haile, E., \& Men, Y. (2007). Costs of occupational injuries in construction in the United States. Accident Analysis and Prevention, 39(6), 1258-1266. https://doi.org/10.1016/j.aap.2007.03.012

Wang, J., Zou, P. X. W., \& L, P. P. (2016). Critical factors and paths influencing construction workers' safety risk tolerances. Accident Analysis and Prevention, 93, 267-279. https://doi.org/10.1016/j.aap.2015.11.027

Waring. (1996). Safety Management Systems. Chapman \& Hall, London.

Wiengarten, F., Humphreys, P., Onofrei, G., \& Fynes, B. (2017). The adoption of multiple certification standards: perceived performance implications of quality, environmental and health \& safety certifications. Production Planning and Control, 28(2), 131-141. https://doi.org/10.1080/09537287.2016.1239847

Woolfson, C., Foster, J., \& Beck, M. (1997). Paying for the Piper: Capital and Labour in Britain's Offshore Oil Industry. Routledge.

Yoon, S. J., Lin, H. K., Chen, G., Y, S., Choi, J., \& Rui, Z. (2013). Effect of occupational health and safety management system on work-related accident rate and differences of occupational health and safety management system awareness between managers in South Korea's construction industry. Safety and Health at Work, 4(4), 201-209. https://doi.org/10.1016/j.shaw.2013.10.002

Zarei, E., Karimi, A., Habibi, E., Barkhordari, A., \& Reniers, G. (2021). Dynamic occupational accidents modeling using dynamic hybrid Bayesian confirmatory factor analysis: An 


\section{Journal of Information System

Volume 6 Issue 24 (December 2021) PP. 90-99 DOI: 10.35631/JISTM.624009

in-depth psychometrics study. Safety Science, 136(July 2020), 105146. https://doi.org/10.1016/j.ssci.2020.105146 